\title{
Sdjitler's Briejwedjiel
}

mit

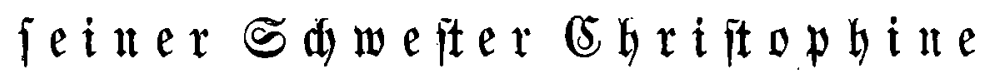

นnธ

feinem Shwager $\mathfrak{A}$ eimwald. 


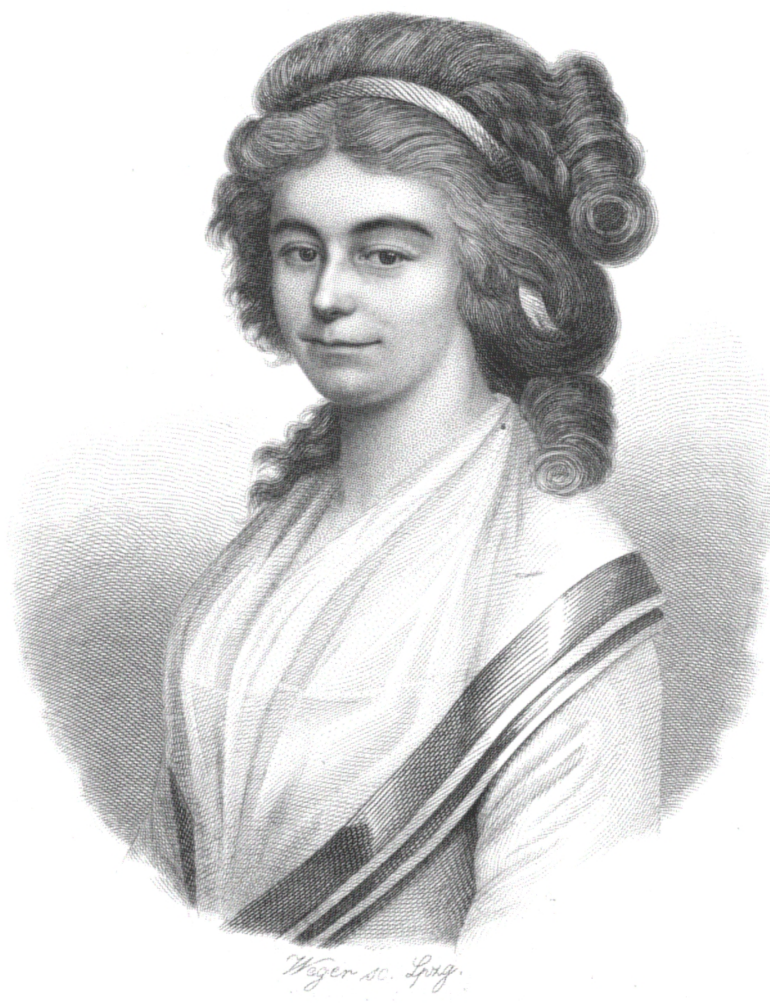






\section{Schiller's Briefwed)iel \\ mit}

\section{feituer Shyefter Shrituphine und}

jeinem Sdwager $\Re$ einwald.

Şeraug̉gegeben

bon

\section{Wendeliit von staltżahn.}

Mit bem Bildnis Der Chriftophine Reinmalb, geb. Sdifller.

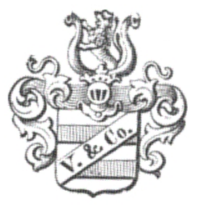

Reipzig

Berlag von Beit \& Eomp.

1875 . 
arle Redte vorbehalten. 